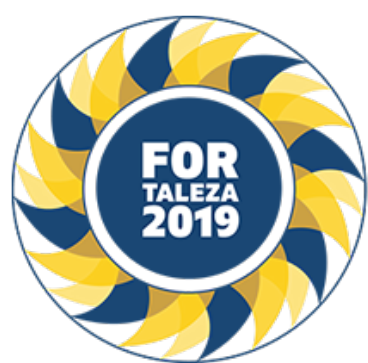

SBR 2019

$36^{\circ}$

CONGRESSO

BRASILEIRO DE

REUMATOLOGIA

CENTRO DE EVENTOS DO CEARÁ O4 A 07 DE SETEMBRO

\section{EVALUATING RELIGIOSITY IN AUTOIMMUNE RHEUMATIC DISEASES}

LISIA LAIANE ABREU GOMES LOIOLA (UNIFOR, FORTALEZA, CE, Brasil), MARINA ISIDÓRIO CRUZ MACEDO (UNIFOR, FORTALEZA, CE, Brasil), MARIANA MACEDO MILITÃO MENDONÇA (UNIFOR, FORTALEZA, CE, Brasil), SAMIA ARAUJO DE SOUSA STUDART (HGF, FORTALEZA, CE, Brasil), MAILZE CAMPOS BEZERRA (HGF, FORTALEZA, CE, Brasil), REJANE MARIA RODRIGUES DE ABREU (HGF, UECE, UNIFOR, FORTALEZA, CE, Brasil)

\section{BACKGROUND}

The old cultures used to attribute healthy and sickness to the power of Gods, so rituals and prayers were made with the aim to get the cure for diseases. Still on the actual context, religion is a source of refuge to the people that has some complaint, and their attitudes and values are frequently influenced by what is sacred. Rheumatic autoimmune diseases like Systemic Lupus Erythematosus (SLE), Rheumatoid Arthritis (RA) and Polymyositis resulting from some disturb on the immune system bring on some damages in multiple organs and reduce their life quality. The Religion can work in these patients by being a vanishing point and a shelter to fight their disease.

\section{MATERIALS AND METHODS}

Transversal quantitative study realized at a public

hospital's ambulatory of Collagenous. It was made an interview with its own questionnaire approaching the religiosity and the evolution of the sickness. The study was approved by the ethics committee, the TCLE was answered by the participants.

\section{RESULTS}

A total of 51 patients were interviewed, in an age group between 18 and 89 , with $80 \%$ of the group composed of women. Sixty three percent of them had the RA diagnosis, $27 \%$ had Polymyositis and $10 \%$ had SLE. Almost one third of the patients had at least one episode of hospitalization, with variation on the time of hospitalization happening in the gap of 1 week to 6 months. Ninety eight percent embraced a religion, contemplating the total of 31 Catholics, 17 evangelicals and 2 Jehovah's Witness. One patient considered himself as atheist. Eighty percent never changed their religion, and $60 \%$ affirmed that had greater attachment after the 
diagnosis. Four patients (8\%) declared that they believe that their disease was a punishment for some occurred fact. Also, $80 \%$ declared that they daily look for their religions and twenty percent only look for their religions when they are in some difficulty. Seventy six percent believe that can cure themselves by means of religion and $53 \%$ get attached to the religious resources, like promises and prayers, with the objective to reach get better on the treatment. Ninety percent realize prayers every day. Between the patients of the masculine sex, the most (64\%) related that didn't hold so much to the religion.

\section{CONCLUSION}

The religiosity proved to be an influent support to the patients who have autoimmune rheumatoid diseases, being commonly used as an emotional and behavioral appeal to fight these pathologies. 